\title{
Understanding the Bases of Entrepreneurship in Kimbanguist Church
}

\section{Edwige Kamitewoko}

Faculty of Economic Sciences, Marien Ngouabi University, Brazzaville, Congo

Email: aijiaae@yahoo.fr

How to cite this paper: Kamitewoko, E. (2021). Understanding the Bases of Entrepreneurship in Kimbanguist Church. Modern Economy, 12, 1245-1262.

https://doi.org/10.4236/me.2021.128065

Received: July 2, 2021

Accepted: August 21, 2021

Published: August 24, 2021

Copyright (c) 2021 by author(s) and Scientific Research Publishing Inc. This work is licensed under the Creative Commons Attribution International License (CC BY 4.0).

http://creativecommons.org/licenses/by/4.0/

\begin{abstract}
The specialized literature offers relevant support for the idea that the entrepreneurship and the private initiative represent the foundation of the economic growth. Despite this evidence, researchers have long established a relationship between religion and entrepreneurship; however, how specific religious beliefs play a role in this relationship remains unknown. Therefore, this study explores the kind of teachings (spiritual message) that kimbanguist church uses to inculcate entrepreneurial intention among 17 million of believers. The research is based on a review of pertinent literature in the field of economic activities, church entrepreneurship and face to face interviews at nkamba new Jerusalem during the three key dates in the Kimbanguist calendar. It proposes to politics to work together with religion (church), to draw inspiration from its lessons in order to boost entrepreneurship and hence the economy.
\end{abstract}

\section{Keywords}

Entrepreneurship, Church, Kimbanguist

\section{Introduction}

The importance of entrepreneurship in economic growth and development, coupled with job creation and poverty alleviation cannot be over-emphasized (Gree \& Thurnik, 2003).

Entrepreneurship is considered as one of the mechanisms of the economic development that have an important role in creating labor and value. Schumpeter (1934) sees entrepreneurship as the major driver behind an economy. Wennekers and Thurik (1999) eloquently state that entrepreneurship is in modern open economies more important for economic growth than it has ever been. Entrepreneurship is fundamental for a well-functioning economy. Social values are 
shown to be important for entrepreneurship, and religion is known to influence social beliefs and aspects. Individuals, in particular believers, transform religious values to their various activities including consumption behaviors, business practices as well as working environment. This is in line with the thoughts of Adam Smith, who argues that religion plays an important role in shaping the economy. Weber (1922) finds that religion played a big role in motivating people to take up entrepreneurial activities. Iannaccone (1998) concludes that "At the level of individuals and households, economic behavior and outcomes do correlate with religion."

Since the new millennium, research on the relationship between religion and work has gained some consideration in economy (Madhu \& Richa, 2020), much has been written about the influence of religion and related beliefs, on economic life or entrepreneurship (Andrew, 2016); Moreover, Guiso, Sapienza and Zingales (2003) find that religious beliefs are associated with higher per capita income and growth. Rabindra et al. (2017) conclude that workplace spirituality positively and significantly increased organizational commitment and job satisfaction. However, little is actually known about the bases (teaching and preaching) that each religion uses to inculcate entrepreneurial culture throughout the believers. It is known that every religion has its own values and beliefs. Besides, the impact on economic activity is not the same across all religions.

This study focuses on kimbanguist church where $98 \%$ of believers are entrepreneurs and Simon kimbangu is a model of entrepreneurship. He has cultivated a theology of liberation (force in nurturing business start-ups and encouraging entrepreneurship among believers) by offering a unique understanding of the Bible which is summarized on trilogy: love, Ten Commandments and works. The key methods in the arousal of the entrepreneurial appetite include nsinsani (strategy used to raise money to get entrepreneurial activities off the ground), teachings diffused within the gathering and during cults which have an effect on entrepreneurial activities. Based on his religious preaching, his moral recommendations have been memorized and kept by his followers.

Therefore, in this study, the relation between kimbanguist church bases and entrepreneurial intention is explored. The main research question driving this study is "what kind of teachings (spiritual message) does kimbanguist church use to inculcate entrepreneurial intention among the believers? In other words: how does the trilogy: love, Ten Commandments and works participate to enactment of entrepreneurial intention among the believers?

\subsection{Study Objectives}

This study explores the kind of teachings (spiritual message) that kimbanguist church uses to inculcate entrepreneurial intention among 17 millions of believers. In other words, we'd like to see how the kimbanguist church teachings participate in the establishment of an entrepreneurial culture among the believers.

Since this is one of the first studies that examine the impact of kimbanguist 
church teachings on entrepreneurial intention, this research is likely to advance our knowledge on the kimbanguist values and entrepreneurial behaviors not only by offering insights into the interface between kimbanguist church, and entrepreneurial intention but also by demonstrating the influence of kimbanguist basic values on the entrepreneurial intention, an area neglected by the previous literature.

\subsection{Organization of the Paper}

The rest of the paper is organized as follows: Chapter two highlights the related literature. Chapter three describes research methodology. The foundation (bases) that positively influence entrepreneurship intention are given in chapter four, chapter five states on How trilogy lead to entrepreneurship and the last chapter is the conclusion part.

\section{Related Literature}

\subsection{Introduction}

For a better understanding the influence of kimbanguist church teachings on entrepreneurial intention, this chapter provides the contextualization of Terms and some highlights of previous research on religion or church and entrepreneurial behavior.

\section{Contextualization of Terms}

1) Church: the church is a community of believers in the Lord, Jesus Christ (Okwueze \& Ononogbu, 2013). Church is also used in reference to formal organizations that are created to preach the gospel of Jesus Christ sustainably under the tutelage of a leader/founder often called Senior Pastor, Bishop, and Apostle, Reverend or Prophet and advancing the Christian doctrine. Protestants, Evangelical, Orthodox communities are also included in the church dimension.

2) kimbanguist: Kimbanguist is the largest independent church in Africa. It takes its name from Simon Kimbangu (1887-1951) which means in Kikongo "the one who reveals the hidden meaning of things". A native of the Lower Congo (born on September 12, 1887, Nkamba, near Thysville, Congo Free State, now Mbanza-Ngungu, Democratic Republic of the Congo), he was a catechist of the Baptist Missionary Society (Baptists; British Missions) in the Ngombe Lutete region. He was reputed to heal the sick and raise the dead, he drew thousands of pilgrims to his hometown of Nkamba to hear his preaching. They left plantations, factories, churches, and hospitals to hear the good news of salvation and liberation that the ngunza (prophet) proclaimed from April 6, 1921.

Although Kimbangu's preaching had no overtly political content, Belgian authorities, alarmed by the disturbances that he provoked, arrested him and his immediate followers in September 1921. Kimbangu was arrested less than six months after his first miracle. He was condemned to death, but his sentence was commuted; he spent the rest of his life in prison in Élisabethville. This Congolese 
religious leader died on October 10, 1951 and after his death, his work was continued by his son Diangienda.

Meanwhile, his followers and imitators spread Kimbanguism, in the Belgian Congo and the neighbouring French Congo and Angola. During the African nationalist ferment of the 1950s, Kimbanguists from Nkamba, led by the youngest of the prophet's three sons, Joseph Diangienda (Diangienda ku Ntima), founded the Kimbanguist church, which received official recognition in December 1959, a year before Congo achieved independence.

This largest independent church in Africa, is a member of the World Council of Christian Churches since 1969, with an estimated membership of 17 millions (Gampiot, 2010). The Kimbanguists are strongest in the Congo area, but have members in other African countries, as well as France, Belgium, the United Kingdom, and the United States. Today, Simon Kimbangu Kiangani (a grandson of Simon Kimbangu who was born on the day of Simon Kimbangu died) the actual head of the church is also the spiritual leader and the legal representative of the Kimbanguist church.

Kimbanguist practices are a blend of different influences. Main church services take place on Sundays. However, prayers are also held everyday morning and afternoon. Polygamy, smoking, drugs, alcohol, the eating of pork, sleeping naked, and trading on Sundays are all forbidden. Kimbanguist church bases her values and believes on the bible which is summarized on trilogy: love, Ten Commandments and works.

\section{3) Entrepreneurship}

Notwithstanding the fact that entrepreneurship is in itself a complicated, ambiguous and changeable phenomenon (Landstrom, 2007), my working definition for entrepreneurship is any deliberate action by groups of people, communities or individuals in starting or engaging in business activities either formally or informally to make a profit. Entrepreneurial stimulation refers to those deliberate attempts to steer or increase entrepreneurship activities.

\subsection{Theoretical Framework}

The theory underpinning this study is the Max Weber's theory titled "the protestant ethic and the spirit of capitalism". Weber's (1930) seminal work on the Protestant Ethic and the Spirit of Capitalism laid the foundation to understand the broad impact of religions and religious institutions on economic activity. Weber argued that God's favor was indicated through personal economic success. This belief led Protestant congregations to work harder, save and reinvest money and find better ways of doing things.

Weber said that religion is the main driving force of entrepreneurship; he believes the traits of a religious individual are a catalyst that would bring about entrepreneurial activities. He theorized that religion is a key determinant of entrepreneurial development and entrepreneurial energies are driven by religious beliefs about causes and consequences. In particular, he emphasized how religions 
can encourage growing capital for investment through the virtues of compound interest. He argues that the most common component of any societies is religion, thereby stating that this historically has shown that religion has been a force for entrepreneurship because it has always argued for it in most scriptures.

His work thus provided some initial insights into the mechanisms of how religion, an arguably personal attribute, can become prevalent in society and affect societal members. A key notion in Weber's work is that individual behavior is guided by religious context.

\subsection{Empirical Review}

The empirical evidence suggests that religion influences the individual's entrepreneurial intention and that there is a strong relationship between religion and entrepreneurship. Religious beliefs and practices significantly influence many different areas of a person's life and especially the economic behavior of different societies. Woodrum (1985) found participation in religious activities to be a predictor of entrepreneurial success among Americans of Japanese origin, values and culture shape the environment for entrepreneurship as well as the entrepreneurial event. Aldrich (1979) noted that the environment could provide or withhold resources. From an anthropological perspective, Stewart (1991) suggested that the legitimization of enterprise was a function of culture. From a sociological perspective, Reynolds (1991) confirmed the importance of non-economic factors, such as the legitimacy of entrepreneurship, for entrepreneurial activity.

Kayed \& Hassan (2010) investigated the impact of Islamic values and entrepreneurship activity in 2010 in Saudi Arabia, he found out that Muslim consider entrepreneurship as religious and economic duty. Another study on Hinduism by Audretsch \& Meyer (2009) aimed at examining the impact of religion on economic behavior of societies in India by 2007, the study found out that Hinduism and its caste system seems to engender a focus on casual labor for individuals under its religious influence, on the other hand the Muslim and Christian community have more desire to engage in self-employment. This is also supported by the works of Audretsch, Boente, \& Tamvada (2007) which examines whether religion has an impact on economic decision. They said that India contains diverse religions; some of the religions positively affect the entrepreneurial decision, such as Islam and Christianity, while others, especially Hinduism, inhibit entrepreneurship. When an individual belongs to a backward caste, also the caste system has a negative effect on entrepreneurship. This can be explained by the limits of freedom of occupational choice in the backward classes. In the case of India the insight of Weber (1930), that religion has an important influence on economic behavior, holds. Actually they only show that religion has a negative as well as a positive influence.

However in the works of Nair \& Pandey (2006), which examines the impact of socio economic and attitudinal characteristics of entrepreneurship in Kerala. The economic status, technical education, age and work experience favor entre- 
preneurship. Religion on the other hand does not support entrepreneurship. This contradicts other studies that have been carried out in this area. Studies on religion are not only centered on the entrepreneurial behavior such as De Noble, Galbraith, Singh, \& Stiles (2007) who tested the proposition that religious orientation has a relationship with Market justice and self-employment. The study found out that religious orientation has a relationship between market justice and self-employment. Other works in the area such as that of Drakopoulou \& George (2007) investigated the inter relationship between religion and enterprise and found out that individuals would use their religious criteria in making informed decisions.

The relationship between religion and economic development has attracted some limited attention from economists. As Iyer (2016) points out, approaching the economy of religion as an established field of knowledge is still relatively new. Among the many interesting features of this research area is religious organization, and how behavior within and between religious organizations is analogous to business behavior, including the phenomenon of competition. Iyer stresses the importance of organizational theory, in particular the principles of marketing and management in the study of religion. The prevailing view is that of religious participation as rational choice (Warner, 1993; Iannaccone, 1998). Whereas the secularization hypothesis focuses on the demand side of the religious market, the rational choice literature introduces greater supply-side focus (Finke \& Iannaconne, 1993; Iannaccone, 1994; McCleary \& Barro, 2006). A key hypothesis in this work has been the importance of religious diversity (or "competition") as feature for societies where religious activity appears to remain strong. Competitive forces in the religious "market" ensure that religious organizations work harder to provide value for members and prospective members, and in consequence may demand and obtain greater levels of commitment (Iannaccone, 1998). Evidence for such "market forces" may be found in indicators for religious pluralism.

There have been many studies about the influence of religious beliefs on entrepreneurial intention, but most of them centered mainly on the other part of the world, not in central Africa and particularly in Congo. Besides, most of the studies centered mainly on Islam, Hinduism, while there has been no studies concerning the kimbanguist church and we know that different religions yield dissimilar patterns for entrepreneurship. The purpose of this paper is to contribute to fill this gap.

Kimbanguism is an example of a religion in which the majority $(98 \%)$ of believers is entrepreneur, it is important to analyze the quaintness of basic message which leads believers to entrepreneurship.

\section{Methodology}

The research was carried out at Nkamba New Jerusalem, in democratic republic of Congo by Laboratory of analysis and research in economic and social research 
(LARES). LARES researchers were conducted at Nkamba by the author who is member of the Kimbanguist church.

There were two main reasons for the selection of Nkamba: firstly, because this is the birthplace of Simon Kimbangu. Secondly, because during church historical dates, kimbanguist believers worldwide arrive there to celebrate these events. And that time give us an opportunity to communicate with the kimbanguist worldwide. Primary data sources are mainly observation by the LARES researchers and face to face interviews during the three key dates (April 6; may 25 and October 12) in the Kimbanguist calendar. Then data collection was performed from April 6 ${ }^{\text {th }}, 2019$ to October 12, 2019.

\subsection{Population}

The sample included 300 entrepreneurs from 17 countries of which 196 were in Africa, 92 were in Europe and 12 were America. Of the 300 entrepreneurs, 116 were men and 184 were women. They were allowed to express their views in the language with which they were most comfortable (English, French, Lingala or kikongo).

\subsection{Sampling Unit}

A kimbanguist entrepreneur whose age varies between 25 and 60 years and whose enterprise satisfied the following two characteristics were regarded as the sampling unit: .having a live business establishment (agriculture, manufacturing, trading or service) and The enterprise is existing for a minimum period of 2 years (demonstrating some sort of success). Inherited enterprises were thus excluded.

\subsection{Data Collection Design}

In the interview, we asked questions related to the link between church teachings and business, duration of being kimbanguist, gathering and cults participation frequency, business history, businesses development experiences in their living place and business establishment such as: when did you started, where did you get the idea from (push factor), what was the primary reason, how much time did it take, did you had experience, what was the biggest challenge, how did you finance the business?

The objective of the interviews was to have conversations with the interviewees without influencing and directing their answers. The researcher personally conducted the interviews in private to limit the possibilities of misunderstandings, and each interview was in excess of two hours long. We were careful not to raise the church teachings topic or its impact on the running for business during the initial component of the interview as we wanted to observe whether the respondent raised them unprompted. The interviews were accompanied by written notes on observation.

A brief economics activities profile of the entrepreneurs is presented in Table 1. 
Table 1. A brief economics activities profile of the sample entrepreneurs.

\begin{tabular}{ccc}
\hline Economics activities & male & female \\
\hline Fish farming & 10 & 10 \\
Farming & 16 & 28 \\
School owner & 8 & 17 \\
Beauty parlor owner & 6 & 30 \\
Banking service provider & 5 & 7 \\
Steel Fabrication owner & 6 & 3 \\
Garage owner & 20 & 12 \\
Restaurant owner & 11 & 27 \\
Garment shop owner & 3 & 14 \\
Grocery shop owner & 8 & 18 \\
Tailing and weaving centre's & 13 & 11 \\
breeding owner & 5 & 10 \\
Brickwork owner & 5 & 7 \\
total & 116 & 184 \\
\hline
\end{tabular}

Source: Interview data.

Main sources of secondary data are websites, newspaper articles and published papers. These are mainly used as a literature base and in some cases validating arguments raised.

\section{The Foundation (Bases)}

The most important biblical message that kimbanguist pastors develop for believers from Monday to Saturday twice a day (morning and afternoon), and every Sunday morning during cults is based on trilogy: love, ten commandment and work.

Let us briefly see the content of this trilogy.

\subsection{What kind of Love?}

Love for God, for the mankind and for all God's creations. So whatever you wish that others would do to you, do also to them, for this is the law and the prophets.

- Matthew 7: 12

The calling to "love our neighbor as we love ourselves" (Matthew 22: 37-39), indicates a great concern and treat to all. It is hard to love a neighbor yet treat them harshly. When we care for other people, we reflect God's character. GOD teaches us to be kind and empathetic towards other people. For entrepreneurs, if you follow what the bible teaches us about love, you will be a kind person and your employees will be happy with you. This can have a positive impact on your business as happy employees tend to be more productive and more productivity means more output, which can generate better returns for you.

"God is love, and as pure love, He is always inclusive, and I believe that we 
should be, too. (Jenmin lin)".

Another believer from Zimbabwe stated "My personal relationship with the Lord inspires me in all I do". Ernest Dimu.

Since God created all human beings in his image and likeness (Genesis 1: 27-28), man is expected to portray God's image in all involvement with fellow human beings.

Israel as a nation was supposed to live as a family, thus share among them what they had. They needed to have strong ties of love and interest, therefore, showing obedience to their God. Just like the early church, Israel lived as a community who worshiped and sanctified in him (Baker, Gedajlovic, \& Lubatkin, 2005). They were required to obey these laws and treat each other as their own and then help the poor. A Chinese saying states, "Give a man a fish, you feed him for a day. Teach a man to fish and you feed him for a lifetime." Believers should learn not only to be kind to the poor, but also show them that one of the best ways for helping them is to train them to be self-sufficient. Training may be better than giving something like money depending on the situation.

\subsection{Ten Commandments (Exodus 20; 1-17)}

God's commands are like those of a loving father who tells his children, "Under no circumstances are you to go out on that busy street!" He's not giving that command to take away their fun, but rather to protect them from danger and death.

The Bible consistently shows that God gives us His commandments for our own good and the good of our families and all society, to bless us when we keep them.

If we disobey any of these commandments, we disobey God. If we break just one link in this chain, we have broken all. The very attempt to keep these commandments alerts us to our inability to do anything to please God outside of our Redeemer, and drives us to Him for mercy (Galatians 3: 24). Sin always promises quick pleasure, but in the long run it damages the sinner and many others.

"The Ten Commandments are the charter and guide of human liberty, for there can be no liberty without the law." Ken Lukini

Foundational principles for right living come from God. Because He created us, He knows the guidelines we need in order to enjoy rich and fulfilling lives. Here, the verse is talking about how the Lord's hand must be in something for it to work properly. It's important to remember that we should rely on the Lord. We shouldn't trust in our own abilities alone-the Lord must be at the heart of everything we do. "Seek first His Kingdom and righteousness and all these other things will be added to you." Unless the LORD builds the house, the builders labor in vain. Unless the LORD watches over the city, the guards stand watch in vain. - Psalm 127: 1. The ten commandments from Exodus 20; 1-17 or ten laws are the bases which some of today's countries use to make up their laws. That will guide you on your way of entrepreneurship.

\subsection{Works}

In Kimbanguist Church, there is much implementation of entrepreneurship 
programs that can fight poverty, explore the levels of knowledge, training, and practices exhibited by church in poverty eradication. These programmes held every year in different recognise place of cult and include farming, breeding, brickworks, beauty parlor, sewing, Knitting, baking cakes (for young mothers, widows) seminaries.

Concerning farming, believers have to get experience in the church plantation where experimented elders members teach youngest about what to plant, which inputs to use and how, when to plow, to seed, to harvest; how much to keep for consumption in the household and how much to sell to raise cash, or how much to store. The same procedure is done about breeding.

Kimbanguist experts in brickworks, beauty parlor, sewing, knitting, baking cakes teach young mothers, widows and all church members want to learn about. After been trained, most of them prefer to work in businesses which are relatively easy to enter and try to avoid risks.

"Never be lazy, but work hard and serve the Lord enthusiastically. Rejoice in our confident hope. Be patient in trouble, and keep on praying". Elisa Cindy

One of the beneficiaries who own the beauty parlor in potopoto market stated: I learnt about beauty parlor after losing my husband, it was terrible; my church was the only one support. I received material and spiritual support, then, I opened my own beauty parlor to practice what I learnt at church.

As a Christian community, Kimbanguist church is responsible for their youth not only in the realm of spirituality and faith, but in their productive work as contributing members of society.

It is worth mentioning that the church is seen as an incubator providing support in terms of accommodation, training, advice and financing. Church raises capital from nsinsani and invests in productive assets in order to finance economic activities launch for those who do not have self-financing. Once the activities are developed, they take charge of themselves and have the obligation to contribute (in kind or in cash) to church development. The model can be summarized like this:

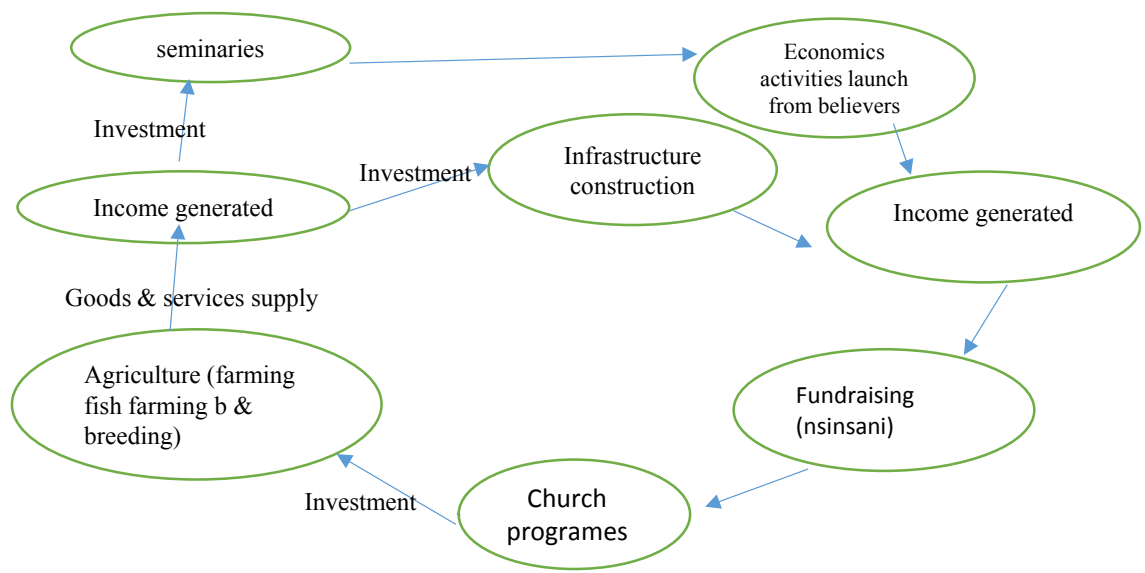

Several strategies or methods are used. One of the methods is called nsinsani 
(Kikongo name for fundraising) that is held once a month. This practice has an important role in the development; in social, economic, financial and entrepreneurial domains.

The Kimbanguist Church was probably forced to use this method of fundraising when in the early 1960 's, their children were kicked out of missionary schools, and Kimbanguist patients were refused admission in mission hospitals.

This economics practice of fundraising helps not only in church infrastructure construction (The money so realized was spent on building dispensaries, hospitals and schools) but also believers by implementing economics projects in agriculture domain; financing socio-economic activities and organizing entrepreneurship seminars empowering them to be independent. Thus, one of the major roles of kimbanguist pastors is to support and grow a community of believers that is not only spiritually healthy, but also economically viable. A pastor typically provides support for followers in the form of prayer, guidance, and financial resources in times of need.

Another method used to inculcate entrepreneurship spirit among followers is called: gathering (lukutakanu in Kikongo language).

It is a meeting which held every Tuesday, where kimbangu vision about entrepreneurship is shown to young people: "tolona, tobokola" which means: let's practice agriculture and Breeding.

One of the grandsons of simon kimbangu every Tuesday insist about work and said: you should cultivate the field as much as you can. When there will abundance, it will reduce the cost of imported products. Whenever there is no work, there is misery. Let us think back of when Moses asked to the Pharaoh to let him take the children of Israel away out of Egypt. Pharaoh was against it because he knew that he would lose his workforce. After 430 years the children started to doubt Gods words. But they were fulfilled. God took the time necessary to have Moses ready. And they left Egypt for the promise land. When the fathers used to say "work" it was for a good reason that time has come. Let us do the work. Anyone called child of Simon KIMBANGU knows the importance of work said Simon KIMBANGU KIANGANI, actual leader of Kimbanguist church. Besides, every morning and afternoon, during cult, the priest reads bible and preaches about thirty minutes, insisting on work by different bible verses stating on labor:

The Bible encourages Christians to work hard and not to be slothful in their businesses. Thus, there is the need to be diligent and conscientious in one's chosen field of endeavor (Proverbs 10: 4; 22: 29; Rom. 12: 11). It is said that Solomon was extremely wealthy, but he had to create his fortune, as much of it did not exist before (I Kings 3, 4: 26). Solomon generated wealth by bringing peace to the kingdom, which allowed him to use his resources for production, rather than protection. In addition, he encouraged trade and was the only Jewish king with a trading fleet (1 Kings 9).

Proverbs 14: 23 points out that, "all hard work brings a profit, but mere talk leads only to poverty". "Lazy hands make a man poor, but diligent hands bring 
wealth" (Proverbs 10: 4).

"Sluggards do not plow in season; so at harvest time they look but find nothing" (Proverbs 20: 4).

"The cravings of sluggards will be the death of them, because their hands refuse to work" (Proverbs 21: 25). In the book of Genesis, God gave the earth with all its resources to Adam and Eve. They were to mix their labor with the raw material of creation to produce usable goods for their family. Similarly, the master in the parable of the talents expected his servants to use the resources at their disposal to increase the value of his holdings. Through this parable, God commands us to use our talents productively; we are exhorted to work, to be creative; we are created to work, to use our minds and our hands to subdue this world and rule over it (Genesis 1:27-28). Scripture praises industriousness and hard work (Proverbs 14: 23; 31: 27; Ephesians 4: 28)

"Entrepreneurial ideas come as a solution from the need to improve something in your city or community. No one knows if your idea is going to be the 'next big thing', but you need to try. Trust in God and don't hear people that say you can't do it. No matter how difficult things are, God will help you with problems, and do the impossible when necessary." Didier Mye

We know that several of the apostles ran a fishing business, and Matthew's tax collecting was a private independent business in those days. In addition, the apostle Paul made tents, Luke practiced medicine, and less-discussed believers operated businesses as well.

It is wrong to depend on the resources of others especially if we're able-bodied enough to do something to earn an income. And as we are earning, we should be planning for a day that will probably come when we aren't able to work as hard or as long.

Simon Kimbangu's model and others biblical passages teaching influence followers' behaviors to have entrepreneurial intention.

\subsection{Simon Kimbangu a Real Model of Entrepreneurship}

A person of Simon Kimbangu is shown to believers as a good example of entrepreneurship to follow. He possessed the most important entrepreneurial characteristics:

\section{- Trust in God}

He Trust in God, he was catechist who evolved into a preacher and heal disease in the name of Jesus. He has a faith and believe that GOD exists and that he is rewards those who earnestly seek him.

\section{- Reasonable Risk-taking,}

He taking risks to please and honor God. When colons questioned him: "do you have money to build church, his answer was: "people is my money".; he was self-confident: trust his own abilities, have a general sense of control in his life, and believe that, within reason, he will be able to do what he wish, plan, and expect.

\section{- Hardworking}


Work elevates a man. His emphasis on what the Bible said: wealth is obtained through hard work, diligence, sacrifice and that failure to do those things will result in poverty.

- Innovative

Kimbangu has the ability to see situations from a different perspective, to discover new ways of satisfying a human need, then he implement the "nsinsani".

\section{- Positive thinker}

Positive thinking is based on biblical principles of self-worth and self-esteem. These principles derive from the fundamental teaching that God created humans in His image and the Christ died to rescue humans from their sins. God has given each of us unique abilities to develop and used to serve others. In its essence, Christian positive thinking is faith in God and his promises that what kimbangu has.

\section{- Decision maker}

He decided to obey to commands of God, and to what Jesus said to him about his ministry.

\section{- Leadership}

He was a true leader, respected all people and presented essential characteristics: courage, enthusiasm, integrity tact, hard work and humble. Humility is a quality of being courteously respectful of others. It is the opposite of aggressiveness, arrogance, boastfulness, and vanity.

He had values summed in Matthew 22: 37-39, "Love the Lord your God with all your heart, soul and your mind. This is the first and greatest commandment. And the second is like it: Love thy neighbor as yourself."

\subsection{How Trilogy Lead to Entrepreneurship}

Everything is first spiritual before to be material: before to create vehicle there is first the spirit of vehicle. For Kimbanguists, the Spirit existed first and then the material. The implication for mission is that the spiritual has influence on the material. This is the same for entrepreneurship.

Let us see how trilogy keys elements (nsinsani; lukutakanu and teaching from bible verses) lead to entrepreneurship

- Nsinsani: from macroeconomic level (church), to microeconomic level (individual)

This fundraising practice helps to finance socio-economic activities such as fish farming. Fish is raised until they are big enough to sell and the most important is that from remainder fish, a big part is distributed to believers who'd like to begin with his own activity. Believers gained material support and spiritual sustenance. And they copy the way that the church acts.

Money gained from this activity is invested in agriculture domain.

"Fundraising is the gentle art of teaching the joy of giving. Great things are done by a series of small things brought together" George Len.

Antonio, one of the entrepreneurs who is from Angola stated:

"The nsinsani was a great opportunity that allowed me to have a better under- 
standing on Christianity. I used this fundraising method at home with my family members. As I used to see in church, money collected at home help me to begin with my business. After five year I built my private school. I employed 30 workers".

\section{- Lukutakanu (gathering)}

Gathering meeting encourage more people especially the young to be part of advancement of the church and implement income generating activities. It is said that every kimbanguist Child must build New Jerusalem, quote from promises and blessings. But, how to build it if you have no income? Then, you have to start, get into entrepreneurship since there are no more jobs.

From bible verse it is state that God does not like the lazy. Since the book of Genesis God asked Adam to work. It is only while working that you will be able to participate in the construction of your church and god will bless you in all your path. Besides, when one colon asked Simon Kimbangu this question: you want to build the church, do you have the money? He answered that my money is people. He knows people by working can earn money, generate income, develop the church and the entire nation. Then, if you are called Kimbanguist, you have to follow his logic.

"The Destiny of Man is to unite, not to divide. There is beauty and power in unity. You will reach your goals only with the help of others. If you keep on dividing you end up as a collection of monkeys throwing nuts at each other out of separate trees." Pascal lendy

Alicia Ota, One female believer from Congo said:

"I was born in a kimbanguist family and started my kimbanguist faith journey at the age of 13 my parent died, but i have kept my faith and prayed every day. When I was at the age of 19, I went to kimbanguist church plantation and worked about three years. I learn more about agriculture during tuesday gathering. I returned in Brazzaville in January 29, 2006 then heard from the pastor that God is the master, He has delivered to each of us, on loan, a portion of his bounty. He doesn't want us standing pat. Whatever he has given, he wants us to multiply. If we don't, he won't be pleased. We'll be punished. From that day, I decided to do something. I started the business selling peanuts and when I got enough money, I invested in agriculture in the production of maize, fruits and vegetables and i also rear small animals. Today, I bought 40 hectares of land and engaged three friends of mine as workers. I'm thankful for everything I got from God."

Thus, the trilogy of kimbanguist church influences the believers to adopt the philosophy and ethics of kimbanguist entrepreneurship. Jason, a young american stated: "after listening to what Simon Kimbangu want us to do, I reacted. I decided to stop waiting from the others, then, I discussed with my parent about my start up. They thank that was a great idea and helped me. Today, they are so happy seeing their son doing business".

Trusting God completely means having faith that He knows what is best for your life. 
Trilogy teachings provided some initial insights into the mechanisms of how church, an arguably personal attribute, can become prevalent in society and affect societal members. Trilogy teachings motivate and encourage the community to dig their potency and dare to act to improve their quality of life, through "nsinsani" for creating awareness and self-ability.

Franck expressed his understanding of the link between his faith which comes with what he heard and his business like this: "everything we do in our business is based on biblical principles. I was thirty three years old when I met a man who was hurt by the car, nobody cared about him. I remembered about love for God, for the mankind and for all God's creations. So whatever you wish that others would do to you, do also to them, for this is the law and the prophets.-Matthew 7: 12. I brought him to the hospital where we spent two weeks. When we came back home, he asked me about my religion and thanks me about my generosity. He told me that he is a management teacher at university. After learning that I have no job, he gave me money for doing business. I started the business selling shop fittings and equipment such as trollies, shopping carts".

Church serve not only as community of prayer but also it creates a sense of community; assisting one another, inculcating entrepreneurial culture which debouche to practice economics activities. Church is key teachers of economical skills.

Octavie, owner of big planting in Mbanza Ngungu in democratic republic of Congo shared his experience and knowledge about the business he dreamed of starting and how kimbanguist teachings pushed her to accomplish what she wanted. He said:

"I was walking on the street near kimbanguist church when i heard a specific sound of kimbanguist fanfare music. Six minutes later i arrived in the main entrance of kimbanguist church, it was predication time and I heard about entrepreneurship in the bible, GOD don't like lazy man this words were like a call . From that day, I began to go there and pray. Every day I heard about trilogy. Then i decided to work in the church farming, after working 5 years under, i had experience, knowledge and skills i should have about farming. Then I decided to open my own farming. This is the first business i had ever dreamed of starting and have done so. Today I have ten workers with me".

As Durkheim (1951 in Cnaan, 1999) said: "religion provides direction and expectations as to the meaning of human existence and defines the obligations of its members to themselves, their family and the broader society", religion as belief system provides not only human spiritual and social but also economic understanding of life.

Roger DaSilva owner of the school in Luanda was born in Angola and currently resides in France. She said: I began my Christian journey at the age of 14 . In my childhood, I experienced wars and saw people killed in the marketplaces ignorantly. Having seen my mother with a strong faith on trilogy, I'm also influenced by it. When I was 22 years old, I was employed as secretary. At workplace, I practiced bible commandment which impressed my director. This 
latter gave me an opportunity to go to France for pursuing my studies. After two years, I came back and began my own business.

\section{Conclusion}

Kimbanguist church has become a significant force in nurturing business startups and encouraging entrepreneurship among believers (98\% of the believers is entrepreneur). The purpose of this study was to explore the kind of teachings (spiritual message) that kimbanguist church uses to inculcate entrepreneurial intention among 17 million of believers. The trilogy: love, Ten Commandments and works participate to enactment of entrepreneurial intention among the believers. The key methods in the arousal of the entrepreneurial appetite include nsinsani, teachings diffused within the gathering and during cults. These methods have a catalytic effect on entrepreneurial intention.

Understanding how the kimbanguist church participates in the establishment of an entrepreneurial culture among the believers may help as bedrock of entrepreneurship to diminish unemployment.

Thus, politics must work together with religion (church) to draw inspiration from its lessons in order to boost entrepreneurship and hence the economy. One church with an economics activities mindset can affect a whole city. It can also change a nation.

\section{Conflicts of Interest}

The author declares no conflicts of interest regarding the publication of this paper.

\section{References}

Aldrich, H. E. (1979). Organizations and Environments. Prentice Hall.

Andrew, H. (2016). Does Religion Influence Entrepreneurial Behavior? International Small Business Journal: Researching Entrepreneurship, 35, 23-35.

Audretsch, D. B., Boente, W., \& Tamvada, J. P. (2007). Religion and Entrepreneurship. Jena Economic Research Papers, 75, 22-36. https://doi.org/10.2139/ssrn.1025968

Audretsch, D. B., \& Meyer, G. D. (2009). Religion, Culture and Entrepreneurship in India. Indiana University Public Affairs Conference.

Gampiot, A. M. (2010). Les Kimbanguistes en France. Expression Messianique d'une Église Afro-Chrétienne en Contexte Migratoire. Paris, L’Harmattan, coll. Théologie et Vie politique de la terre.

Baker, T., Gedajlovic, E., \& Lubatkin, M. (2005). A Framework for Comparing Entrepreneurship Processes across Nations. Journal of International Business Studies, 36, 492-504. https://doi.org/10.1057/palgrave.jibs.8400153

De Noble, A., Galbraith, C. S., Singh, G., \& Stiles, C. H. (2007). Market Justice, Religiousorientation, and Entrepreneurial Attitudes: An Empirical Study. Journal of Enterprising Communities: People and Places in the Global Economy, 1, 121-134. https://doi.org/10.1108/17506200710752548

Drakopoulou, D. S., \& Gotsis, G. (2007). The Interrelationships between Entrepreneurship and Religion. The International Journal of Entrepreneurship and Innovation, 8 , 
93-104. https://doi.org/10.5367/000000007780808066

Durkheim, R. A. (1999). Empowerment through Organized Religion. In W. Shera, \& L. Wells (Eds.), Empowerment Practice in Social Work: Developing Richer Conceptual Foundations (pp. 93-105). Canadian Scholar Press.

Finke, R., \& Iannaccone, L. R. (1993). Supply-Side Explanations for Religious Change. The Annals of the American Academy of Political and Social Sciences, 5, 27-39.

Guiso, L., Sapienza, P., \& Luigi, Z. (2003). People's Opium? Religion and Economic Attitudes. Journal of Monetary Economics, 50, 225-282. https://doi.org/10.1016/S0304-3932(02)00202-7

Gree, A., \& Thurnik, C. (2003). Firm Selection and Industry Evolution: The Post Country Performance of New Firm. Journal of Evolutionary Economics, 4, 243-264.

Iannaccone, L. R. (1998). Introduction to the Economics of Religion. Journal of Economic Literature, 36, 1465-1495.

Iannaccone, L. (1994). Why Strict Churches Are Strong. American Journal of Sociology, 99, 1180-1211. https://doi.org/10.1086/230409

Iyer, S. (2016). The New Economics of Religion. Journal of Economic Literature, 54, 395-441. https://doi.org/10.1257/jel.54.2.395

Kayed, R. N., \& Hassan, K. (2010). Islamic Entrepreneurship. London: Routledge.

Landstrom, H. (2007). Pioneers in Entrepreneurship. Small Business Research, 8, 23-36.

Madhu, L., \& Richa, C. (2020). Workplace Spirituality and Incivility at Work: A Conceptual Framework. 9th Annual Meeting of the Academy of Management (AOM), August 9-13, Massachusetts.

McCleary, R. M., \& Robert J. B. (2006). Religion and Economy. Journal of Economic Perspectives, 20, 49-72. https://doi.org/10.1257/jep.20.2.49

Nair, K. R. G., \& Pandey, A. (2006). Characteristics of Entrepreneurs: An Empirical Analysis. Journal of Entrepreneurship, 15, 47-61. https://doi.org/10.1177/097135570501500104

Okwueze, M. I., \& Ononogbu, D. C. (2013). The Church and Entrepreneurship-Hope for the Youth in Nigeria. Journal of Religion and Human resources, 3, 5.

Reynolds, P. D. (1991). Sociology and Entrepreneurship: Concepts and Contributions. Entrepreneurship Theory and Practice, 16, 47-70. https://doi.org/10.1177/104225879201600205

Rabindra, K. P., Sanjay K. S., Lalatendu K. J. (2017). Workplace Spirituality, Organizational Commitment and Job Satisfaction: A Study. Academy of Management, Annual Meeting.

Schumpeter, J. A. (1934). The Theory of Economic Development: An Inquiry into Profits, Capital, Credit, Interest, and the Business Cycle. Harvard University Press.

Stewart, A. (1991). A Prospectus on the Anthropology of Entrepreneurship. Entrepreneurship Theory and Practice, 16, 71-91.

Warner, S. R. (1993). Work in Progress toward a New Paradigm for the Sociological, Study of Religion in the U.S. American Journal of Sociology, 98, 44-93.

https://doi.org/10.1086/230139

Weber, M. (1922). Economy and Society. University of California Press.

Weber, M. (1930). The Protestant Ethic and The Spirit of Capitalism. T. Parsons, Trans., Allen Unwin.

Wennekers, A. R. M., \& Thurik A. R. (1999). Linking Entrepreneurship and Economic Growth. Small Business Economics, 13, 27-55. 
https://doi.org/10.1023/A:1008063200484

Woodrum, E. M. (1985). Religion and Economics among Japanese Americans: A Weberian Study. Social Forces, 64, 191-204. https://doi.org/10.2307/2578979

\section{Other References}

Ephesians 4:28, Holy Bible: King James Version.

Exodus 20; 1-17, Holy Bible: King James Version.

Galatians 3:24, Holy Bible: King James Version.

Genesis 1:27-28, Holy Bible: King James Version.

I Kings 3, 4:26, Holy Bible: King James Version.

1 Kings 9, Holy Bible: King James Version.

Matthew 7:12, Holy Bible: King James Version.

Matthew 22:37-39, Holy Bible: King James Version.

Proverbs 10:4; 22: 29, Holy Bible: King James Version.

Proverbs 14:23, Holy Bible: King James Version.

Proverbs 20:4, Holy Bible: King James Version.

Proverbs 21:25, Holy Bible: King James Version.

Proverbs 14:23; 31:27, Holy Bible: King James Version.

Psalm 127:1, Holy Bible: King James Version.

Rom. 12:11; I, Holy Bible: King James Version. 